\title{
Retreatment with Interferon-Alpha and Ribavirin in Primary Interferon-Alpha Non-Responders with Chronic Hepatitis C
}

\author{
Gerlinde Teuber ${ }^{a}$ Thomas Berg ${ }^{b}$ Robert M. Hoffmann ${ }^{c}$ Ludger Leifeld $^{d}$ \\ Michael Lafrenz ${ }^{\mathrm{e}}$ Ulrich Spengler ${ }^{\mathrm{d}}$ Gerd R. Pape $^{\mathrm{c}}$ Uwe Hopf $^{\mathrm{b}}$ \\ Stefan Zeuzem ${ }^{\text {a }}$ \\ a Medizinische Klinik II, Klinikum der Johann-Wolfgang-Goethe-Universität, Frankfurt, \\ bUniversitätsklinikum Charité, Campus Virchow-Klinikum, Berlin, \\ c Medizinische Klinik II, Klinikum Grosshadern, Ludwig-Maximilians-Universität, München, \\ dMedizinische Klinik, Klinikum der Rheinischen Friedrich-Wilhelm-Universität, Bonn, und \\ eKlinik und Poliklinik, Klinikum der Universität Rostock, Deutschland
}

\section{Key Words}

Interferon- $\alpha$ /ribavirin retreatment $\cdot$ Interferon

non-responder $\cdot$ Chronic hepatitis $\mathrm{C}$

\begin{abstract}
Background/Aims: Combination therapy with interferon$\alpha$ (IFN- $\alpha$ ) plus ribavirin is more efficacious than IFN- $\alpha$ monotherapy in previously untreated patients with chronic hepatitis $\mathrm{C}$ and patients with IFN- $\alpha$ relapse. Only limited data are available in IFN- $\alpha$ non-responders. In a multicenter trial we therefore evaluated the efficacy of combination therapy in IFN- $\alpha$-resistant chronic hepatitis C. Methods: Eighty-two patients (mean age 46.8 years, 54 males, 28 females) with chronic hepatitis $C$ were treated with IFN- $\alpha-2 a(3 \times 6 \mathrm{MIU} /$ week) and ribavirin (14 mg/kg daily) for 12 weeks. Thereafter, treatment was
\end{abstract}

Dedicated to Prof. Dr. med. Dr. med. vet. Dr. h.c. K.H. Meyer zum Büschenfelde on the occasion of his 70th birthday.

Gerlinde Teuber, Thomas Berg and Robert M. Hoffmann contributed equally to this study.

\begin{tabular}{ll}
\hline KARGER & ( ) 2000 S. Karger AG, Basel \\
$0012-2823 / 00 / 0612-0090 \$ 17.50 / 0$ \\
$\begin{array}{l}\text { Fax +4161306 12 34 } \\
\begin{array}{l}\text { E-Mail karger@karger.ch } \\
\text { www.karger.com }\end{array}\end{array}$ & $\begin{array}{l}\text { Accessible online at: } \\
\text { www.karger.com/journals/dig }\end{array}$
\end{tabular}

continued only in virological responders (undetectable serum HCV RNA at week 12) with an IFN- $\alpha$ dose of $3 \times$ $3 \mathrm{MIU} /$ week and without ribavirin for a further 9 months. The primary study endpoint was an undetectable HCV RNA by RT-PCR at the end of the 24-week follow-up period. Results: After 12 weeks of combination therapy, an initial virological response was observed in 29 of 82 (35.4\%) patients. Due to a high breakthrough rate after IFN- $\alpha$ dose reduction and ribavirin discontinuation, an end-of-treatment response was only achieved in 12 of 82 $(14.6 \%)$ patients. After the follow-up period, a sustained virological response was observed in 8 of 82 (9.8\%) patients. Infection with HCV genotype 3 was the only pretreatment parameter, which could predict a sustained response (HCV-1, 5\%; HCV-3, 57.1\%; p < 0.001). Conclusions: Despite a high initial response rate of $35.4 \%$, sustained viral clearance was achieved only in $9.8 \%$ of the retreated primary IFN- $\alpha$ non-responders. Higher IFN- $\alpha$ induction and maintenance dose, as well as prolonged ribavirin treatment may possibly increase the virological response rates in non-responders, particularly in those infected by HCV-1.

Copyright $@ 2000$ S. Karger AG, Basel
Prof. Stefan Zeuzem, MD

Medizinische Klinik II, Theodor-Stern-Kai 7

D-60590 Frankfurt (Germany)

Tel. +49696301 5122, Fax +496963014807

E-Mail Zeuzem@em.uni-frankfurt.de 


\section{Introduction}

Hepatitis $\mathrm{C}$ virus ( $\mathrm{HCV}$ ) infection is a common cause of chronic liver disease and may progress to liver cirrhosis and hepatocellular carcinoma in a substantial proportion of infected individuals [1-4]. At the end of interferon- $\alpha$ (IFN- $\alpha$ ) monotherapy with 3 MIU three times weekly subcutaneously for 6-12 months, a virological response with apparent clearance of serum HCV RNA can be achieved in $30-40 \%$ of patients. However, during followup relapses occur in $50-80 \%$ of these patients. Therefore, IFN- $\alpha$ monotherapy with 3 MIU three times weekly subcutaneously for 6-12 months may induce a sustained virological response in only $10-20 \%$ of patients with chronic hepatitis C [5-8].

Recently published studies indicated a synergistic therapeutic effect of orally administered ribavirin added to standard IFN- $\alpha$ treatment in chronic hepatitis $C$ [9-12]. Ribavirin (1- $\beta$ - $D$-ribofuranosyl-1,2,4,-triazole-3-carboxamide) is a synthetic guanosine analogue with a broad spectrum of antiviral activities against several DNA and RNA viruses, including flaviviruses [13-15]. Furthermore, ribavirin exhibits immunomodulatory effects, e.g. shifting the balance of pro-inflammatory and anti-inflammatory cytokines towards a Th1 response by inhibiting the Th2 cytokine production [16].

Compared with IFN- $\alpha$ monotherapy, combination treatment with IFN- $\alpha$ and ribavirin for 6-12 months improves the long-term virological response rates to approximately $40-50 \%$ in patients with chronic hepatitis C [17-21]. The combination treatment is highly effective in the retreatment of patients with chronic hepatitis $C$ relapsing after primary IFN- $\alpha$ monotherapy [22-24]. IFN- $\alpha /$ ribavirin combination therapy has recently been registered in the United States for treatment of chronic hepatitis C and is awaiting further approval in several European countries. However, the therapeutic value of combined IFN- $\alpha$ and ribavirin retreatment is controversially discussed in patients with chronic hepatitis $\mathrm{C}$ who did not respond to a primary IFN- $\alpha$ treatment $[22,23,25-27]$.

Therefore, the aims of the present study were to evaluate the therapeutic efficacy and the tolerability of retreatment with combined IFN- $\alpha$ /ribavirin as an induction therapy for 12 weeks followed by maintenance therapy with IFN- $\alpha$ alone for 9 months in a cohort of patients with chronic hepatitis $\mathrm{C}$ who failed to respond to primary IFN$\alpha$ monotreatment. In addition, potential parameters predicting a sustained response, such as age, sex, disease duration, ALT, AST, $\gamma$-GT, pretreatment viral load, HCV genotype, and the absence of cirrhosis, were analyzed.

\section{Patients and Methods}

In this prospective, open and uncontrolled multicenter trial, 82 patients with chronic hepatitis $\mathrm{C}$ not responding to previous IFN- $\alpha$ monotherapy with a minimal total IFN- $\alpha$ dose of $108 \mathrm{MIU}$ and a treatment duration of at least 12 weeks were enrolled during December 1995 and November 1996. Patients were eligible when they met all of the following inclusion criterias: (1) non-response to a previous IFN- $\alpha$ treatment with persistence of serum HCV RNA; (2) a treatment-free interval of at least 24 weeks; (3) elevated ALT levels; (4) a positive anti-HCV test; (5) detectable serum HCV RNA; (6) compensated liver disease; (7) baseline hemoglobin of at least $11.0 \mathrm{~g} / \mathrm{dl}$, and (8) age between 18 and 70 years. Demographic, biochemical and virological pretreatment characteristics are summarized in detail in table 1. Hepatitis B virus or human immunodeficiency virus type 1 and 2 coinfection as well as concomitant autoimmune disease and metabolic disorders were excluded by appropriate biochemical and serological tests. Further exclusion criteria were severe concurrent diseases, including malignancy, systemic immunosuppressive treatment within the last 24 weeks prior to study begin and a history of depression. Liver biopsy was performed in all patients before initiation of the primary IFN- $\alpha$ therapy. In 58 patients an additional biopsy was obtained within 12 months before retreatment. In the 24 patients, who refused a liver biopsy at this time, the result of the biopsy before the primary IFN- $\alpha$ treatment was considered for histological classification (table 1). No histological result in these 24 patients was older than 47 (mean 24; range 12-47) months. Inflammatory activity and extent of fibrosis were histologically assessed according to the 1994 revised classification of chronic hepatitis [28].

\section{Measurement of Serum HCV RNA}

Serum HCV RNA was assessed by a standardized qualitative reverse transcription-polymerase chain reaction (RT-PCR) assay (Amplicor HCV ${ }^{\circledR}$, Hoffmann-La Roche, Germany) [29]. Individual pretreatment serum HCV RNA concentrations and HCV genotype (according to the classification of Simmonds et al. [30]) were determined by quantitative RT-PCR (Amplicor Monitor HCV 1.0 ${ }^{\circledR}$, Hoffmann-La Roche, Germany) and a reverse hybridization assay (Inno LiPA HCV II ${ }^{\circledR}$, Innogenetics, Belgium), respectively [30-33].

\section{Study Design}

All patients were treated with 6 MIU IFN- $\alpha$-2a thrice weekly subcutaneously and ribavirin $(14 \mathrm{mg} / \mathrm{kg}$ of body weight daily, i.e. $600-$ $1,200 \mathrm{mg}$ ) in two divided doses orally for 12 weeks (fig. 1). Thereafter, ribavirin therapy was discontinued in all patients, while IFN- $\alpha$ treatment was reduced to 3 MIU thrice weekly and continued for additional 9 months only in patients with undetectable serum HCV RNA at treatment week 12 . The follow-up period was 24 weeks in all patients. Clinical examination and laboratory assessments, including blood count and aminotransferases, were performed between pretreatment weeks 4-12, at the initiation of treatment, every 2 weeks for the first 12 weeks of treatment and monthly thereafter until the end of treatment. Follow-up visits were scheduled 4, 12 and 24 weeks after discontinuation of treatment. Serum HCV RNA was quantitatively assessed before initiation of treatment, and qualitatively at 3 and 12 months during treatment as well as at the end of the follow-up period.

The study protocol was approved by the local ethics committees for medical research of the participating study centers according to the Declaration of Helsinki. Because all patients enrolled in the present study were previous IFN- $\alpha$ non-responders, a retreatment 
Table 1. Demographic, clinical, biochemical, virological and histological parameters in 82 non-responders to previous IFN- $\alpha$ monotherapy with chronic hepatitis $\mathrm{C}$

\begin{tabular}{|c|c|}
\hline \multicolumn{2}{|l|}{ Demography } \\
\hline Age, years & $46.8 \pm 10.3(26-70)$ \\
\hline Sex, males/females & $54 / 28$ \\
\hline \multicolumn{2}{|l|}{ Mode of transmission } \\
\hline Posttransfusional & $32(39.0 \%)$ \\
\hline Intravenous drug abuse & $11(13.4 \%)$ \\
\hline Occupational & $2(2.4 \%)$ \\
\hline Sexual & $1(1.2 \%)$ \\
\hline Unknown & $36(44.0 \%)$ \\
\hline Disease duration, years ${ }^{1}$ & $12.3 \pm 8.7(1-36)$ \\
\hline \multicolumn{2}{|l|}{ Primary treatment } \\
\hline Total IFN- $\alpha$ dose, MIU & $360 \pm 184(108-1,248)$ \\
\hline Duration, months & $6.6 \pm 3.0(3-14)$ \\
\hline \multicolumn{2}{|l|}{ Biochemistry $^{2}$} \\
\hline $\mathrm{ALT}, \mathrm{U} / 1$ & $80 \pm 57(25-338)$ \\
\hline $\mathrm{AST}, \mathrm{U} / 1$ & $43 \pm 34(4-250)$ \\
\hline$\gamma-\mathrm{GT}, \mathrm{U} / 1$ & $52 \pm 41(4-277)$ \\
\hline Albumin, g/dl & $4.6 \pm 0.5(3.5-5.7)$ \\
\hline Bilirubin, $\mu \mathrm{mol} / 1$ & $13.7 \pm 6.8(5.1-35.9)$ \\
\hline Prothrombin time, $\%$ & $101 \pm 14(65-133)$ \\
\hline \multicolumn{2}{|l|}{ Virology } \\
\hline HCV RNA positive & 82 \\
\hline HCV RNA, $\times 10^{6}$ copies $/ \mathrm{ml}^{3}$ & $1.022 \pm 0.894(0.001-3.334)$ \\
\hline \multicolumn{2}{|l|}{ HCV genotype } \\
\hline HCV-1 & $60(73.2 \%)$ \\
\hline $\mathrm{HCV}-2$ & $2(2.4 \%)$ \\
\hline $\mathrm{HCV}-3$ & $7(8.6 \%)$ \\
\hline $\mathrm{HCV}-4$ & $2(2.4 \%)$ \\
\hline Unclassifiable & $2(2.4 \%)$ \\
\hline Not assessed & $9(11.0 \%)$ \\
\hline \multicolumn{2}{|l|}{ Histology } \\
\hline \multicolumn{2}{|l|}{ Inflammatory activity } \\
\hline Minimal to mild & 44 \\
\hline Moderate to severe & 38 \\
\hline \multicolumn{2}{|l|}{ Fibrosis score } \\
\hline $0-3$ & 49 \\
\hline 4 (cirrhosis) & 33 \\
\hline
\end{tabular}

ALT $=$ Alanine aminotransferase; AST = aspartate aminotransferase; $\gamma$-GT $=\gamma$-glutamyltranspeptidase. The values are given as the mean \pm SD (range), or number of patients.

1 Disease duration was defined as the time between the first diagnosis of hepatitis $\mathrm{C}$ or previous non-A, non-B hepatitis later on confirmed as hepatitis $\mathrm{C}$.

2 Normal reference ranges: 4-23 U/1 for ALT, 6-18 for AST, 4-28 for $\gamma-G T, 35-55 \mathrm{~g} / \mathrm{l}$ for albumin, 3.4-23.9 $\mu \mathrm{mol} / \mathrm{l}$ for bilirubin, 70 $130 \%$ for prothrombin time.

3 Pretreatment serum HCV RNA concentration was quantitatively assessed in 60 of 82 patients. arm with IFN- $\alpha$ monotherapy as a control group was refused for ethical reasons [34-37]. Informed written consent was obtained from all patients.

\section{Definition of Response and Study Endpoints}

Virological response to treatment was defined as undetectable serum HCV RNA by qualitative RT-PCR (sensitivity 1,000 copies/ $\mathrm{ml}$ ) at treatment week 12 ('initial virological response'), at the end of treatment and at the end of follow-up ('sustained virological response'). At the same time points the biochemical response, defined as an ALT value within the normal range, was evaluated. The primary endpoint of this study was undetectable serum HCV RNA at the end of the follow-up period. Secondary efficacy parameters were the initial virological response and the virological end-of-treatment response. As additional secondary endpoints the biochemical responses were analyzed at the corresponding time points.

\section{Statistical Analysis}

Statistical analysis was based on an intention-to-treat methodology. Patients who discontinued treatment or were lost during followup were considered as virological and biochemical non-responders. Data are presented as mean \pm standard deviation (range). Potential pretreatment response predicting parameters were identified by univariate analysis. Continuous and dichotomous variables were analyzed by Student's $t$ test and the $\chi^{2}$ test, respectively.

\section{Results}

\section{Biochemical and Virological Response}

After 12 weeks combined IFN- $\alpha$ and ribavirin retreatment an initial virological response with undetectable serum HCV RNA at week 12 was achieved in 29 of 82 (35.4\%) patients with chronic hepatitis $\mathrm{C}$ not responding to a primary IFN- $\alpha$ monotherapy (table 2 ). The initial virological response was associated with normalization of ALT levels in 21 of 29 of these patients. An isolated initial biochemical response without clearance of serum HCV RNA was achieved in 15 of $82(18.3 \%)$ patients. According to the protocol, however, treatment was discontinued in patients with normal ALT values at week 12, when serum HCV RNA was still detectable. After reduction of the IFN- $\alpha$ dose from $3 \times 6$ to $3 \times 3 \mathrm{MIU} /$ week and discontinuation of ribavirin treatment, a breakthrough with recurrence of serum HCV RNA was observed in 17 of 29 $(58.6 \%)$ patients with an initial virological response. The breakthrough occurred in most patients within treatment months 4-6 (range 4-8 months). Due to this high breakthrough rate, a virological end-of-treatment response was observed in only 12 of $82(14.6 \%)$ patients. Aminotransferase levels had normalized in 7 of 12 patients with a virological end-of-treatment response. During the followup period, 4 of 12 patients with a virological end-of-treatment response relapsed. Thus, a virological sustained 
Fig. 1. Study design.

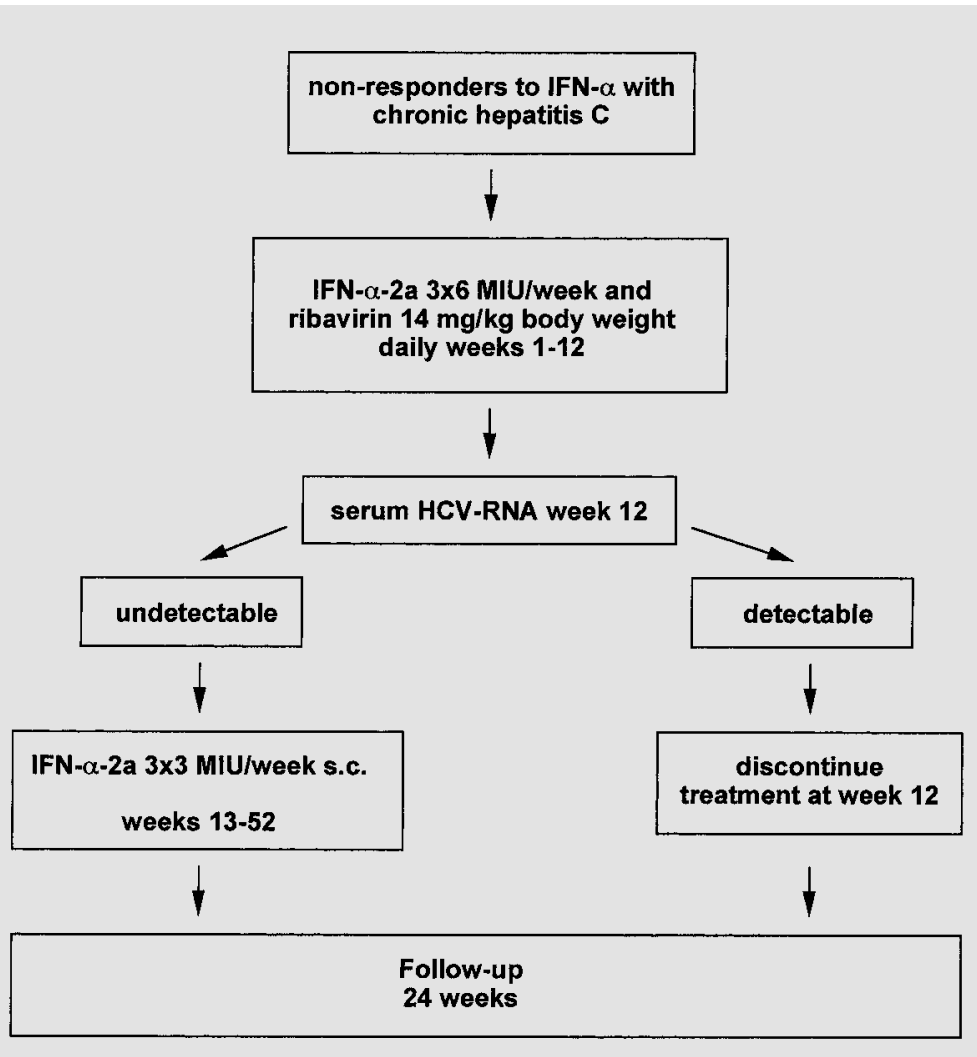

Table 2. Biochemical and virological response to IFN- $\alpha$ /ribavirin retreatment in 82 non-responders to previous monotherapy at treatment week 12 , at end of treatment and end of follow-up

response with undetectable serum HCV RNA after 24 weeks of follow-up was achieved only in 8 of $82(9.8 \%)$ primary IFN- $\alpha$ non-responders with chronic hepatitis C. Seven of these patients also revealed normal ALT values. Furthermore, in 4 additional patients normalization of ALT levels was observed at the end of follow-up despite persisting hepatitis $\mathrm{C}$ viremia.

\section{Predictors of a Sustained Virological Response to Retreatment}

Potential clinical, biochemical, virological and histological pretreatment response predictors were analyzed in patients with a sustained virological response and compared with patients without a sustained virological response (table 3 ). Using a univariate model, only infection

Digestion 2000;61:90-97 93 
Table 3. Univariate analysis of pretreatment parameters possibly predicting a sustained virological response to IFN- $\alpha$ /ribavirin retreatment in primary IFN- $\alpha$ non-responders with chronic hepatitis $\mathrm{C}$

\begin{tabular}{|c|c|c|c|}
\hline & $\begin{array}{l}\text { Sustained virological } \\
\text { responders } \\
(\mathrm{n}=8)\end{array}$ & $\begin{array}{l}\text { Virological } \\
\text { non-responders } \\
(\mathrm{n}=74)\end{array}$ & $\mathrm{p}$ \\
\hline Age, years & $46.1 \pm 13.9(28-63)$ & $46.9 \pm 10.0(26-70)$ & 0.8509 \\
\hline Sex & & & 0.5658 \\
\hline Male & 6 & 48 & \\
\hline Female & 2 & 26 & \\
\hline Disease duration, years ${ }^{1}$ & $8.9 \pm 6.1(3-20)$ & $12.7 \pm 8.9(1-36)$ & 0.2401 \\
\hline $\mathrm{ALT}, \mathrm{U} / 1$ & $82 \pm 37(32-141)$ & $80 \pm 59(25-338)$ & 0.9280 \\
\hline AST, U/1 & $43 \pm 17(21-68)$ & $43 \pm 36(2-250)$ & 0.9930 \\
\hline$\gamma-\mathrm{GT}, \mathrm{U} / 1$ & $35 \pm 28(11-92)$ & $54 \pm 44(4-227)$ & 0.2679 \\
\hline$\gamma$-GT/ALT & $0.48 \pm 0.26(0.18-0.73)$ & $0.80 \pm 0.58(0.09-3.3)$ & 0.1580 \\
\hline $\begin{array}{l}\text { Serum HCV RNA concentration, } \\
\times 10^{6} \text { copies } / \mathrm{ml}^{2}\end{array}$ & $0.149 \pm 0.051(0.103-0.204)$ & $1.068 \pm 0.893(0.001-3.334)$ & 0.1182 \\
\hline $\mathrm{HCV}$ genotype ${ }^{3}$ & & & $<0.0001$ \\
\hline HCV-1 & 3 & 57 & \\
\hline HCV-3 & 4 & 3 & \\
\hline Histology & & & 0.1946 \\
\hline Absence of cirrhosis & 7 & 42 & \\
\hline Cirrhosis & 1 & 32 & \\
\hline
\end{tabular}

\footnotetext{
ALT $=$ Alanine aminotransferase; AST $=$ aspartate aminotransferase; $\gamma$-GT $=\gamma$-glutamyltranspeptidase. Values are given as mean $\pm \mathrm{SD}$ (range), or number of patients.

1 Disease duration was defined as the time between first diagnosis of hepatitis $\mathrm{C}$ or previously non-A, non-B hepatitis later on confirmed as hepatitis $\mathrm{C}$.

2 Pretreatment serum HCV RNA concentration was assessed in 60 of 82 patients.

3 HCV genotype was unclassifiable or not determined in 11 patients.
}

with HCV genotype 3 was associated with the development of a sustained virological response. Clearance of serum HCV RNA was achieved in 4 of 7 (57.1\%) patients infected with HCV genotype 3 compared with 3 of 60 $(5 \%)$ patients with HCV genotype 1 infection $(p<0.001)$. In our patients previously not responding to primary IFN$\alpha$ treatment, no relation was found between a sustained response to combined antiviral retreatment and the patients' age, disease duration, ALT, AST, $\gamma-\mathrm{GT}, \gamma-\mathrm{GT} /$ ALT, individual pretreatment serum HCV RNA concentration or the presence of cirrhosis.

\section{Side Effects}

Nearly all patients $(n=77 ; 93.9 \%)$ developed at least one adverse event during the treatment period. Most side effects $(n=284)$ occurred during the initial 12 weeks of IFN- $\alpha$ /ribavirin combination therapy (table 4). Mild to moderate flu-like symptoms were the most frequently observed adverse events. During ribavirin treatment $19.5 \%$ of the treated patients developed anemia with a serum hemoglobin level of $<11.0 \mathrm{~g} / \mathrm{dl}$. The ribavirin dose was reduced in 14 patients to $7 \mathrm{mg} / \mathrm{kg}$ body weight daily or discontinued ( $\mathrm{n}=4$ patients) due to hemoglobin levels of $<10.0 \mathrm{~g} / \mathrm{dl}$, fatigue, weakness, dizziness, depression, nausea, and vomiting. A reduction of the IFN- $\alpha$ dose from 6 to 3 MIU thrice weekly before week 12 was necessary in 7 patients due to leukopenia, weakness, depression, myalgia, arthralgia, and headache, respectively. In 3 additional patients, both drugs were discontinued due to adverse events at treatment weeks 1 (nausea, diarrhea), 4 (depression), and 12 (anemia, nausea, dizziness), respectively. During IFN- $\alpha$ treatment with $3 \times 3 \mathrm{MIU} /$ week (weeks 13-52) most side effects improved or resolved. Further dose reductions were not required. After discontinuation of treatment, all reported side effects were fully reversible. Serious adverse events were not observed in any patient during the entire treatment period. The drop-out of 1 patient at month 4 of treatment was not related to side effects. After the end of treatment, 3 patients did not attend the scheduled follow-up visit at week 24 . 
Table 4. Side effects of combined IFN- $\alpha$ /ribavirin retreatment (weeks 1-12) followed by IFN- $\alpha$ monotherapy (weeks 13-52) in 82 primary IFN- $\alpha$ non-responders with chronic hepatitis $\mathrm{C}$

\begin{tabular}{|c|c|c|}
\hline Adverse event & $\begin{array}{l}\text { IFN- } \alpha / \text { ribavirin } \\
\text { weeks } 1-12 \\
(\mathrm{n}=82)\end{array}$ & $\begin{array}{l}\text { IFN- } \alpha \\
\text { weeks 13-52 } \\
(\mathrm{n}=29)\end{array}$ \\
\hline \multicolumn{3}{|l|}{ Flu-like } \\
\hline Chills and fever & $56(68.3 \%)$ & $2(6.9 \%)$ \\
\hline Fatigue & $46(56.1 \%)$ & $6(20.7 \%)$ \\
\hline Headache & $22(26.8 \%)$ & $4(13.8 \%)$ \\
\hline Myalgia & $13(15.9 \%)$ & $2(6.9 \%)$ \\
\hline Arthralgia & $8(9.8 \%)$ & $2(6.9 \%)$ \\
\hline \multicolumn{3}{|l|}{ Gastrointestinal } \\
\hline Nausea & $21(25.6 \%)$ & $1(3.5 \%)$ \\
\hline Loss of appetite & $9(11.0 \%)$ & 0 \\
\hline Diarrhea & $4(4.9 \%)$ & 0 \\
\hline \multicolumn{3}{|l|}{ CNS } \\
\hline Insomnia & $11(13.4 \%)$ & $2(6.9 \%)$ \\
\hline Depression & $8(9.8 \%)$ & $1(3.5 \%)$ \\
\hline Disturbances of concentration & $2(2.4 \%)$ & $2(6.9 \%)$ \\
\hline Weakness & $7(8.5 \%)$ & 0 \\
\hline Dizziness & $9(11.0 \%)$ & 0 \\
\hline \multicolumn{3}{|l|}{ Dermatological } \\
\hline Hair loss & $7(8.5 \%)$ & $4(13.8 \%)$ \\
\hline Pruritus & $6(7.3 \%)$ & 0 \\
\hline Rash & $2(2.4 \%)$ & 0 \\
\hline Sicca syndrome & $3(3.7 \%)$ & $1(3.5 \%)$ \\
\hline \multicolumn{3}{|l|}{ Respiratory } \\
\hline Dry cough & $6(7.3 \%)$ & 0 \\
\hline Dyspnea & $1(1.2 \%)$ & 0 \\
\hline \multicolumn{3}{|l|}{ Blood count } \\
\hline Anemia $^{1}$ & $16(19.5 \%)$ & $1(3.5 \%)$ \\
\hline Leucopenia $^{2}$ & $20(24.4 \%)$ & $2(6.9 \%)$ \\
\hline Thrombocytopenia ${ }^{3}$ & $7(8.5 \%)$ & $3(10.4 \%)$ \\
\hline \multicolumn{3}{|l|}{1 Hemoglobin $<10 \mathrm{~g} / \mathrm{dl}$. } \\
\hline \multicolumn{3}{|l|}{$2 \quad$ Leukocytes $<4.0 / \mathrm{nl}$} \\
\hline $3 \quad$ Platelets $<100 / \mathrm{nl}$ & & \\
\hline
\end{tabular}

\section{Discussion}

In this multicenter trial, efficacy and tolerability of combined IFN- $\alpha$ and ribavirin treatment were prospectively assessed in patients with chronic hepatitis $\mathrm{C}$ not responding to a previous IFN- $\alpha$ treatment. This trial was designed in 1994 and it was originally anticipated that ribavirin may exhibit direct antiviral effects. Thus, the rational for the study design was an induction phase with IFN- $\alpha$ plus ribavirin to achieve optimal initial response rates followed by IFN- $\alpha$ monotherapy to maintain the virological response. With respect to the reported poor response rates in non-responders receiving IFN- $\alpha$ retreatment [34-37], a control group with patients receiving IFN- $\alpha$ alone was not justifiable for ethical considerations. As previously described, sustained loss of serum HCV RNA regularly leads to considerable histological improvement $[38,39]$. Thus, a second liver biopsy after retreatment was not performed in our patients and serum HCV RNA 24 weeks after treatment was analyzed as the primary efficacy parameter in this study.

In the present study, including 82 primary IFN- $\alpha$ non-responders, a virological sustained response was achieved in only $9.8 \%$ of patients retreated with a combination of IFN- $\alpha$ and ribavirin. Despite an initially high virological response rate of $35.4 \%$ after 12 weeks of combination therapy, a virological end-of-treatment response was observed in only $14.6 \%$ of the retreated non-responders with chronic hepatitis $\mathrm{C}$. Breakthrough with the recurrence of serum HCV RNA was observed in 15 of 17 patients with an initial response within 3 months after discontinuation of ribavirin therapy and IFN- $\alpha$ dose reduction. In the remaining 2 patients' breakthrough occurred at 7 and 8 months, respectively. Thus, low-dose IFN- $\alpha$ monotherapy is not able to maintain the high initial response rate induced by IFN- $\alpha$ /ribavirin induction therapy. However, as in untreated patients receiving combination therapy, the relapse rate in patients with a virological end-of-treatment response was lower than described for patients after IFN- $\alpha$ monotherapy [20, 21].

In previously published pilot studies concerning IFN- $\alpha$ /ribavirin retreatment in IFN- $\alpha$ non-responders, the reported sustained response rates varied considerably between 0 and $30 \%$ [22, 23, 25-27]. In contrast to the treatment schedule used in this trial, the duration of IFN$\alpha /$ ribavirin retreatment was in general at least 24 weeks. In the present study, the sustained low virological response rate to IFN- $\alpha$ /ribavirin retreatment appears to be related to the short duration of ribavirin treatment and possibly to early IFN- $\alpha$ dose reduction. However, the majority of the previous studies revealed, in accordance with our results, low overall virological sustained response rates of approximately $10 \%$ in non-responders with chronic hepatitis $\mathrm{C}[22,25,27]$. With respect to the $\mathrm{HCV}$ genotype distribution, the present study showed a beneficial therapeutic effect of IFN- $\alpha$ /ribavirin retreatment in non-responders infected by $\mathrm{HCV}$ genotypes 3 with a virological sustained response rate of $57.1 \%$. The results of this trial indicate that the retreatment schedule with an IFN- $\alpha$ /ribavirin induction therapy followed by a low-dose 
IFN- $\alpha$ monotherapy seems not to be effective in nonresponders, infected with $\mathrm{HCV}$ genotype 1 . Thus, the varying response rates, reported in the published pilot studies, may be explained by small study populations and the HCV genotype distribution.

In the present study, other host and viral factors associated with a response to antiviral therapy in untreated patients with chronic hepatitis $\mathrm{C}$, including sex, presence of cirrhosis and pretreatment viral load [40, 41], showed no predictive role in the setting of IFN- $\alpha$ /ribavirin retreatment in non-responders. The lack of an association between the individual serum HCV RNA concentrations and the response to treatment in our patients may be explained by the limitations of the HCV RNA quantification assay used in this study. As previously described, amplification of this commercially available RT-PCR assay is not linear and not genotype-independent leading to an underestimation of the serum HCV RNA concentration in patients with high viremia $\left(>10^{6}\right.$ copies $\left./ \mathrm{ml}\right)$ and patients infected with genotype HCV-2 and $3[30,31]$.
During IFN- $\alpha$ /ribavirin retreatment, side effects occurred in most of our patients $(93.9 \%)$ within the first 3 months of treatment. Most side effects were mild and transient. However, dose reduction or discontinuation of IFN- $\alpha$ and/or ribavirin therapy were required in 28 of 82 $(34.1 \%)$ patients due to the reported adverse events. After discontinuation of treatment, all side effects were fully reversible.

In summary, retreatment with IFN- $\alpha$ and ribavirin in the applied dose regimen seems to have a beneficial therapeutic effect only in non-responders with chronic hepatitis $\mathrm{C}$ infected with HCV genotype 3, while it is of low efficacy in non-responders with HCV genotype 1 infection. Thus, similar to untreated patients with chronic hepatitis C, genotype-dependent therapeutic strategies should be evaluated in the retreatment of non-responders. Furthermore, the potential therapeutic value of a high-dose IFN- $\alpha$ induction and maintenance therapy as well as prolonged treatment with ribavirin, and the addition of amantadin has to be elucidated in future studies.

\section{References}

1 Alter MJ, Margolis HS, Krawczynski K, Judson FN, Mares A, Alexander WJ, Hu PJ, Miller JK, Gerber MA, Sampliner RE, Meeks EL, Beach MJ, for the Sentinel Counties Chronic Non-A, Non-B Hepatitis Study Team: The natural history of community-acquired hepatitis $\mathrm{C}$ in the United States. N Engl J Med 1992;327: 1899-1905.

2 Di Bisceglie AM: Hepatitis C. Lancet 1998; 351:351-355.

3 Tong MJ, El-Farra NS, Reikes AR, Co RL: Clinical outcomes after transfusion associated hepatitis C. N Engl J Med 1995;332:18991905.

4 Saito I, Miyamura T, Ohbayashii A, Harada H, Katayama T, Kikuchi S, Watanabe Y, Koi S, Onji M, Ohta Y: Hepatitis C virus infection is associated with the development of hepatocellular carcinoma. Proc Natl Acad Sci USA 1990; 87:6547-6549.

5 Poynard T, Leroy V, Cohard M, Thevenot T, Mathurin P, Opolon P, Zarski JP: Meta-analysis of interferon randomized trials in the treatment of viral hepatitis C. Effects of dose and duration. Hepatology 1996;24:778-789.

6 Tong MJ, Reddy KR, Lee WM, Pockros PJ, Hoefs JC, Keeffe EB, Hollinger FB, Heathcote EJ, White H, Foust RT, Jensen DM, Krawitt EL, Fromm H, Black M, Blatt LM, Klein M, Lubina $\mathrm{J}$, and the Consensus Interferon Study Group: Treatment of chronic hepatitis $\mathrm{C}$ with consensus interferon: A multicenter, randomized trial. Hepatology 1997;26:747-754.
7 Kagawa T, Hosoi K, Takashimizu S, Kawazoe $\mathrm{K}$, Mochizuki $\mathrm{K}$, Wasada $\mathrm{M}$, Nagata $\mathrm{N}$, Uchiyama J, Nakano A, Nishizaki Y, Watanabe N, Matsuzaki S: Comparison of two interferon alfa treatment regimens characterized by an early virological response in patients with chronic hepatitis C. Am J Gastroenterol 1998; 93:192-196

8 Zeuzem S, Lee JH, Franke A, Rüster B, Prümmer O, Herrmann G, Roth WK: Quantification of the initial decline of serum hepatitis $\mathrm{C}$ virus RNA and response to interferon alfa. Hepatology 1998;27:1149-1156.

9 Reichard O, Andersson J, Schvarcz R, Weiland $\mathrm{O}$ : Ribavirin treatment for chronic hepatitis $\mathrm{C}$. Lancet 1991;337:1058-1061.

10 Di Bisceglie AM, Shindo M, Fong TL, Fried MW, Swain MG, Bergasa NV, Axiotis CA, Waggoner JG, Park Y, Hoofnagle JH: A pilot study of ribavirin therapy of chronic hepatitis C. Hepatology 1992;16:849-854.

11 Brillanti S, Garson J, Foli M, Whitby K, Deaville R, Masci C, Miglioli M, Barbara L: A pilot study of combination therapy with ribavirin plus interferon alfa for interferon alfa-resistant chronic hepatitis C. Gastroenterology 1994; 107:812-817.

12 Bracconier JH, Paulsen O, Engman K, Widell A: Combined alpha-interferon and ribavirin treatment in chronic hepatitis C: A pilot study. Scand J Infect Dis 1995;27:325-329.

13 Patterson JL, Fernandez-Larsson R: Molecular mechanisms of action of ribavirin. Rev Infect Dis 1990;12:1132-1146.
14 Sidwell R, Hoffman J, Kharp L, Allen LB, Witkowski JT, Robins RK: Broad spectrum activity of virazole: 1-beta- $D$-ribofuranosyl-1,2,3triazole-3-carboxamide. Science 1972;117: 705-706.

15 McCormick JB, King IJ, Webb PA, Scribner CL, Craven RB, Johnson KM, Elliott LH, Belmont-Williams R: Lassa fever: Effective treatment with ribavirin. N Engl J Med 1986;314: 20-26.

16 Ning Q, Brown D, Parodo J, Cattral M, Gorczynski R, Cole E, Fung L, Liu MF, Ding JW, Liu MF, Rotstein O, Phillips MJ, Levy G: Ribavirin inhibits viral induced macrophage production of tumor necrosis factor, interleukin-1 and procoagulant activity and preserves Th1 cytokine production, but inhibits Th2 cytokine response. J Immunol 1998;160:34873493.

17 Lai MY, Kao JH, Yang PM, Wang JT, Chen PJ, Chan KW, Chu JS, Chen DS: Long-term efficacy of ribavirin plus interferon alfa in the treatment of chronic hepatitis C. Gastroenterology 1996;111:1307-1312.

18 Reichard O, Schvarcz R, Weiland O: Therapy of hepatitis C: Alpha interferon and ribavirin. Hepatology 1997;26(suppl):108-111.

19 Schalm SW, Hansen BE, Chemello L, Bellobuono A, Brouwer JT, Weiland O, Cavaletto L, Schvarcz R, Ideo G, Alberti A: Ribavirin enhances the efficacy but not the adverse effects of interferon in chronic hepatitis C. J Hepatol 1997;26:961-966.

Teuber/Berg/Hoffmann/Leifeld/Lafrenz/ Spengler/Pape/Hopf/Zeuzem 
20 Reichard O, Norkrans G, Frydén A, Braconier JH, Sönnerborg A, Weiland O, for the Swedish Study Group: Randomised, double blind, placebo-controlled trial of interferon- $\alpha-2 b$ with and without ribavirin for chronic hepatitis $\mathrm{C}$. Lancet 1998;351:83-87.

21 Poynard T, Marcellin P, Lee S, Niederau C, Minuk G, Ideo G, Bain V, Heathcote J, Zeuzem S, Trepo C, Albrecht J, for the International Hepatitis Interventional Therapy Group: Randomized trial of interferon alpha2b plus ribavirin for 48 or for 24 weeks versus interferon alpha2b plus placebo for 48 weeks for treatment of chronic infection with hepatitis $\mathrm{C}$ virus. Lancet 1998;352:1426-1432.

22 Brillanti S, Miglioli M, Barbara L: Combination antiviral therapy with ribavirin and interferon alfa in interferon alfa relapsers and nonresponders: Italian experience. J Hepatol 1995; 23(suppl 2):13-16.

23 Schalm SW, Brouwer JT, Chemello L, Alberti A, Bellobuono A, Ideo G., Schwartz R, Weiland $\mathrm{O}$ : Interferon-ribavirin combination therapy for chronic hepatitis C. Dig Dis Sci 1996; 41(suppl):131-134.

24 Davis GL, Esteban-Mur R, Rustigi V, Hoefs J, Gordon S, Trepo C, Schiffman ML, Zeuzem S, Craxi A, Ling MH, Albrecht J, for the International Hepatitis Interventional Therapy Group: Interferon alfa-2b alone or in combination with ribavirin for the treatment of relapse of chronic hepatitis C. N Engl J Med 1998;339: 1493-1499.

25 Kakamu S, Yoshioka K, Wakita T, Ishikawa T, Takayanagi M, Higashi Y: A pilot study of ribavirin and interferon beta for the retreatment of chronic hepatitis C. Gastroenterology 1993; 105:507-512.

26 Schvarcz R, Ando Y, Sönnerborg A, Weiland $\mathrm{O}$ : Combination treatment with interferon alfa-2b and ribavirin for chronic hepatitis $\mathrm{C}$ in patients who failed to respond to achieve a sustained response to interferon alone: Swedish experience. J Hepatol 1995;23(suppl 2):17-21.
27 Bellobuono A, Mondazzi L, Tempini S, Silini E, Vicari F, Ideo G: Ribavirin and interferonalpha combination therapy vs. interferon-alpha alone in the treatment of chronic hepatitis $\mathrm{C}$ : A randomized clinical trial. J Viral Hepat 1997; 4: 185-191.

28 Desmet V, Gerber M, Hoofnagle JH, Manns M, Scheuer PJ: Classification of chronic hepatitis: Diagnosis, grading and staging. Hepatology 1994;19:1513-1520.

29 Zeuzem S, Rüster B, Roth WK: Clinical evaluation of a new polymerase chain reaction (Amplicor $^{\mathrm{TM}} \mathrm{HCV}$ ) for detection of hepatitis C virus. Z Gastroenterol 1994;32:342-347.

30 Simmonds P, Holmes EC, Cha TA, Chan SW, McOmish F, Irvine B, Beall E, Yap PL, Kolberg J, Urdea MS: Classification of hepatitis C virus into six major genotypes and a series of subtypes by phylogenetic analysis of the NS-5 region. J Gen Virol 1993;74:2391-2399.

31 Roth WK, Lee JH, Rüster B, Zeuzem S: Comparison of two quantitative hepatitis $\mathrm{C}$ virus reverse transcriptase PCR assays. J Clin Microbiol 1996;34:261-264

32 Hawkins A, Davidson F, Simmonds P: Comparison of plasma virus load among individuals infected with hepatitis $\mathrm{C}$ virus (HCV) genotypes 1, 2, and 3 by Quantiplex HCV RNA assay versions 1 and 2, Roche Monitor assay, and an in-house limiting dilution method. J Clin Microbiol 1997;35:187-192.

33 Lee JH, Roth WK, Zeuzem S: Evaluation and comparison of different hepatitis $\mathrm{C}$ virus genotyping and serotyping assays. J Hepatol 1997; 26:1001-1009.

34 Gerken G, Teuber G, Goergen B, Meyer zum Büschenfelde $\mathrm{KH}$ : Interferon-alpha retreatment in chronic hepatitis C. J Hepatol 1995; 22(suppl 1):118-121.

35 Alberti A, Chemello L, Noventa F, Cavalletto L, De Salvo G: Therapy of chronic hepatitis C: Retreatment with alpha interferon. Hepatology 1997;26(suppl 1):137-142.
36 Chow WC, Boyer N, Pouteau M, Castelnau C, Martinot-Peignoux M, Martins-Amado V, Degos F, Maghinici C, Sinegre M, Benhamou JP, Degott C, Erlinger S, Marcellin P: Re-treatment with interferon alfa of patients with chronic hepatitis C. Hepatology 1998;27: 1144-1148.

37 Heathcote EJL, Keeffe EB, Lee SS, Feinmann SV, Tong MJ, Reddy KR, Albert DG, Witt K, Blatt LM, and the Consensus Interferon Study Group: Retreatment of chronic hepatitis C with consensus interferon. Hepatology 1998; 27:1136-1143.

38 Marcellin P, Boyer N, Gervais A, Martinot M, Pouteau M, Castelnau C, Kilani A, Areias J, Auperin A, Benhamou JP, Degott C, Erlinger $\mathrm{S}$ : Long-term histologic improvement and loss of detectable intrahepatic HCV-RNA in patients with chronic hepatitis $\mathrm{C}$ and sustained response to interferon-alpha therapy. Ann Intern Med 1997;127:875-881.

39 Shiffman ML, Hofmann CM, Thompson EB, Ferreira-Gonzalez A, Contos MJ, Koshy A, Luketic VA, Sanyal AJ, Mills AS, Garrett CT: Relationship between biochemical, virological, and histological response during interferon treatment of chronic hepatitis C. Hepatology 1997;26:780-785.

40 Martinot-Peignoux M, Marcellin P, Pouteau M, Castelnau C, Boyer N, Poliquin M, Degott C, Descombes I, Le Breton V, Milotava V, Benhamou JP, Erlinger S: Pretreatment serum hepatitis $\mathrm{C}$ virus RNA levels and hepatitis $\mathrm{C}$ virus genotype are the main and independent prognostic factors of sustained response to interferon alfa therapy in chronic hepatitis C. Hepatology 1995;22:1050-1056.

41 Davis GL, Lau JYN: Factors predictive of a beneficial response to therapy of hepatitis $\mathrm{C}$. Hepatology 1997;26(suppl 1):122-127. 